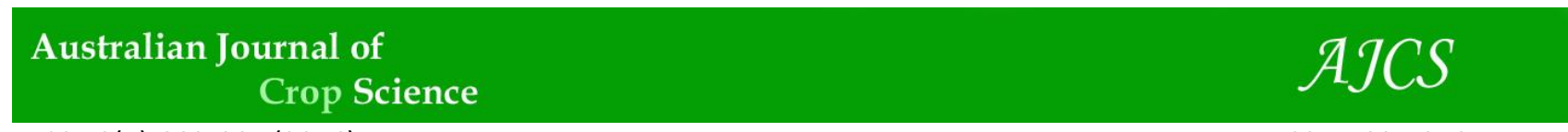

AJCS 10(5):660-665 (2016)

ISSN:1835-2707

DOI: 10.21475/ajcs.2016.10.05.p7359

\title{
Accelerated ageing as a vigour test for crambe (Crambe abyssinica) seeds
}

\author{
Érica Fernandes Leão ${ }^{* 1}$, Juliana Faria dos $\operatorname{Santos}^{1}$, Rafael Marani Barbosa ${ }^{2}$, Roberval Daiton Vieira ${ }^{1}$ \\ ${ }^{1}$ UNESP - São Paulo State University, Department of Plant Production, 14884-900, Jaboticabal, SP, Brazil \\ ${ }^{2}$ DCAA/UESC - Santa Cruz State University, Department of Agrarian and Environmental Sciences, 45662-900, \\ Ilhéus, BA, Brazil
}

*Corresponding author: erica.agronomia@hotmail.com

\begin{abstract}
Adequate seed vigour tests are fundamental in evaluating vigour level and consequent performance of seed lots in storage and in the field conditions. The accelerated ageing is one of the most important of these tests. To establish the best accelerated ageing procedure for evaluating the vigour of crambe seeds, we compared results from the traditional method (ageing periods of 24, 48, and 72 hours at temperatures of 41 and $45^{\circ} \mathrm{C}$ ) and the saturated salt accelerated ageing (SSAA) (NaCl) method. In addition to accelerated ageing, germination in a sand substrate, seedling emergence in laboratory, and seed moisture content before and after seed ageing were determined. Our first count was highly sensitive in detecting seed vigour level. Both the traditional and SSAA methods can be used to efficiently classify the vigour of crambe seed lots and could be promising techniques for crambe seed quality control programs. To evaluate vigour of crambe seed lots, the traditional accelerated ageing test should be executed for 48 hours at $41{ }^{\circ} \mathrm{C}$ and the SSAA method, for 24 hours at 41 or $45^{\circ} \mathrm{C}$. Seedling assessment should be carried out on the fourth day for both methodologies.
\end{abstract}

Keywords: Brassicaceae, physiological potential, procedure adjustments, seed quality, vigour methodologies.

Abbreviations: AA_Accelerated Ageing, CV_Coefficient of Variation, FC_First Germination Count, GE_Germination, RH_Relative Humidity, SEL_Seedling Emergence in Laboratory Soil Substrate, SSAA_Saturated Salt Accelerated Ageing, SMC_Seed Moisture Content, SMCi_Initial Seed Moisture Content.

\section{Introduction}

The genus Crambe is a member of the Brassicaceae family and comprises more than 30 species found mainly in the Mediterranean, Euro-Siberian, and Turkish-Iranian regions. The only cultivated species is Crambe abyssinica (Hochst. Ex R.E. Fr.), which is grown in the United States and Europe for hay (30 to $32 \%$ of raw protein) and erucic acid, which is used as a biodegradable replacement for mineral oils (Desai, 2004). Although studies are scarce, this oleaginous species is an attractive crop mainly because of its rusticity, short crop cycle (about 90 days), low production cost and high potential for biofuels (oil seed content $=26-38 \%$ ), although the studies about it are scarce until today (Paulose et al., 2010). Successful cultivation of crambe starts with establishing the right plant population in the field. This in turn requires seeds of high sanitary and physiological quality. Yield reductions may be indirectly connected to low seed vigour if the resulting plant population does not meet minimum standards required for that crop (TeKrony and Egli, 1991; ISTA, 2000; Marcos-Filho, 2005). Seed lots with similar germination rates frequently exhibit different physiological performance in the field, resulting in seedlings with different levels of vigour, particularly under stressful environmental conditions. Therefore, developing standardized and reproducible methods of testing the vigour of crop seed lots is essential (Vieira et al., 2003; Kikuti and Marcos-Filho, 2008). Accelerated ageing is a vigour test that subjects seeds to high temperature and moisture levels. The degree to which these environmental conditions affect seed performance depends on the initial physiological potential of the seed lot. Unlike low vigour seeds, high vigour seeds will maintain performance even after exposure to these stressful conditions. The accelerated ageing test is influenced by a number of factors such as seed moisture, sample size, ageing temperature, and test exposure time. Reliable results depend on adequate temperatures (species dependent) that are carefully monitored and maintained to avoid variations that could significantly affect results (Panobianco and MarcosFilho, 1998; Marcos-Filho, 1999a; TeKrony, 2003). Seed exposure times at pre-established temperatures have been determined to differentiate the physiological potential of seed lots of small seed species such as onions ( 72 hours at $41{ }^{\circ} \mathrm{C}$ ) (TeKrony, 1995), cauliflower ( 48 hours at $41{ }^{\circ} \mathrm{C}$ ) (Kikuti and Marcos-Filho, 2008) and cabbage ( 48 hours at $42{ }^{\circ} \mathrm{C}$ ) (Costa et al., 2008). Relative humidity is maintained at high levels (usually close to $100 \%$ ) during the ageing process. Under these conditions, seeds, especially small ones, deteriorate substantially and germination rates drop drastically. Therefore, alternative procedures for the accelerated ageing test have been investigated for these species (Powell, 1995; Panobianco and Marcos-Filho, 1998). Relative humidity in saturated salt accelerated ageing - SSAA is lower than that of the traditional procedure. Replacing pure water with a saturated salt solution means that seeds absorb less water, which slows ageing process (Jianhua and McDonald, 1997). The test has been widely studied and found efficient for brassicas (Costa et al., 2008), melon (Torres and MarcosFilho, 2003), arugula (Ramos et al., 2004), pumpkin and zucchini (Dutra and Vieira, 2006), and beetroot (Silva et al., 
2006). Although studies on the SSAA test are relatively numerous, some factors affecting the precision of results such as temperature and seed ageing duration must still be determined for several species, and methods should be standardized. Therefore, the objective of this study was to establish the best accelerated ageing procedure for evaluating the vigour of crambe seeds.

\section{Results}

\section{Characterization of physiological potential}

Initial characterization of the seed lots showed that eight out of the ten lots germinated at rates higher than the minimum (80\%) established for the commercialization of crambe seeds (Table 1). Lots 9 and 10, however, germinated at 69 and $49 \%$, respectively. Seed moisture levels before seed ageing varied between 7.8 and $8.6 \%$ (Table 1). This relatively narrow variation is essential for consistent results are to be expected (Marcos-Filho, 1999b).

The results of the first germination count showed that the vigour of lots 1,2, 3, 4, and 5 was classified as high whereas the vigour of lots 9 and 10 was classified as low (Table 1). This test was efficient at detecting differences among seed lots and made it possible to classify seed lots into four vigour categories. These results agree with those from a study on brassicas (Costa et al., (2008), which concluded that the first germination count could be used to detect small differences in the physiological potential of seed lots. The laboratory seedling emergence test produced data that were consistent and comparable with other parameters and could be used to classify the 10 seed lots into four vigour levels (Table 1).

Considering all the evaluation tests, lot 1 was classified as of high vigour and lot 10 as low vigour (Table 1 ).

\section{Accelerated ageing test: traditional and saturated salt solution methods}

The traditional method of accelerated ageing test caused the crambe seeds to gain moisture throughout the ageing process with the greatest gain during the first 24 hours (Table 2). Table 2 shows that during the first period, seed moisture content increased by approximately 18 percentage points whereas in the next 48 and 72 hours the gains were respectively, of seven and three percentage points (Table 2). All the seed lots had similar moisture content before and after seed ageing procedure and within the variation limits recommended for reliable results (Marcos-Filho, 2005).

Results on the $4^{\text {th }}$ day of the accelerated ageing test at 41 ${ }^{\circ} \mathrm{C}$ and three exposure times (24, 48 and 72 hours) showed that 24 hours of ageing allowed classification into three vigour levels. Lots $1,3,5$, and 7 were the best, indicating the high quality of these lots and corroborating the results of the initial germination count (Table 3). Seed ageing for 48 and 72 hours showed that the seed lots could be classified into four vigour levels, similar to the results of the first count (Table 3). These ageing periods led to the classification of lot 1 as high vigour and lots 3, 9, and 10 as low vigour. Seventytwo hours of exposure may have drastically affected some seeds and severely reduced germination (as observed for lots 2 and 9, Table 3). Therefore, 48 hours of seed ageing at 41 ${ }^{\circ} \mathrm{C}$ appeared to provide the best conditions for detecting differences in the physiological potential of crambe seed lots. Kikuti and Marcos-Filho (2008) studied cauliflower seeds and also found that seed ageing for 48 hours produced more consistent results than did 72 hours.
Given the low values found on the $4^{\text {th }}$ day, another evaluation was made on the $5^{\text {th }}$ day, which showed even lower sensitivity for detecting differences in vigour level (Table 3 ). On the $5^{\text {th }}$ day, the seed lots could only be classified into only two (24 and 48 hours) and three (72 hours) vigour levels (Table 3).

The effects of the $45{ }^{\circ} \mathrm{C}$ treatment were more drastic than those caused by longer exposure times (Table 4). At 24 hours, the seed lots were grouped into three levels with lots 1 and 3 classified as vigorous (Table 4). The 24 hour period was efficient since it produced lot classifications that were similar to those of the first germination count. Seed ageing for 48 hours at $45{ }^{\circ} \mathrm{C}$ drastically reduced seed germination and when the period was extended to 72 hours at $45^{\circ} \mathrm{C}$, some seed lots completely failed to germinate (Table 4 ).

Evaluations on the $5^{\text {th }}$ day also revealed low germination rates, possibly indicating severe seed damage due to higher temperature $\left(45^{\circ} \mathrm{C}\right)$ and longer exposure (Table 4). The 24 hour period allowed high germination rates, but had low sensitivity for differences in vigour as only two levels were found.

The saturated salt accelerated ageing (SSAA) test produced better results than those of the traditional procedure (Table 5) in which evaluations were made only at the first count (fourth day) since the effects of the test were less damaging to the seeds. The SSAA test at $41{ }^{\circ} \mathrm{C}$ and 24 hours allowed differentiation of five vigour levels of which lot 1 was the most vigorous and lot 10 the least (Table 5). This procedure was highly sensitive for detecting small differences in the vigour of crambe seeds.

The 48 hour period was unsatisfactory because it allowed classification of only two groups (Table 5). The results of the 72 hour period, however, were similar to those of the seedling emergence in laboratory test with four vigour levels and good discrimination between similar samples (Table 5).

The accelerated ageing with saturated salt solution test at 45 ${ }^{\circ} \mathrm{C}$ was also efficient at classifying crambe seed lots but severely affected germination rates relative to the same test at $41{ }^{\circ} \mathrm{C}$ (Table 5). Similar to the test at $41{ }^{\circ} \mathrm{C}$, ageing for 24 hours stratified the seed lots into five vigour levels. The 48 and 72 hour periods yielded five vigour levels but with severe reductions in germination rates that could compromise test results.

Seed moisture content after the SSAA test was lower than that of the traditional method (Table 2). It should also be considered that this procedure resulted in seed moisture contents more uniform than those of the traditional method the variation among seed lots was of only 2 percentage points (Table 2). Thus, the traditional accelerated ageing test of crambe seeds should be carried out for 48 hours at $41{ }^{\circ} \mathrm{C}$, whereas the saturated salt solution method should be performed for 24 hours at either 41 or $45{ }^{\circ} \mathrm{C}$. Seedling assessment should be carried out on the fourth day for both tests.

\section{Discussion}

The high germination rates of the crambe seed lots (Table 1) recommend seed vigour testing since, as argued by MarcosFilho (1999b), vigour tests are even more useful and efficient when the seed lots under examination produce high and consistent germination results. Similar initial moisture levels for crambe seeds (6.5 to 9.4\%) were found by Masetto et al. (2009) and Werner et al. (2013). The success of the first germination count (Table 1) might be explained by the fact that one of the first physiological characteristics affected by seed deterioration is germination speed. The advantages of 
Table 1. Initial seed moisture content (SMC), germination (GE), first germination count (FC) and seedling emergence in laboratory soil substrate (SEL) of ten lots of crambe seeds.

\begin{tabular}{|c|c|c|c|c|}
\hline Lots & SMC & GE & FC & SEL \\
\hline & & 1 & - & \\
\hline 1 & 8.5 & $94 a^{1}$ & $71 \mathrm{a}$ & $82 \mathrm{a}$ \\
\hline 2 & 8.0 & $87 \mathrm{a}$ & $78 \mathrm{a}$ & $67 \mathrm{~b}$ \\
\hline 3 & 8.0 & $82 \mathrm{a}$ & $80 \mathrm{a}$ & $73 \mathrm{~b}$ \\
\hline 4 & 8.6 & $88 \mathrm{a}$ & $79 a$ & $69 \mathrm{~b}$ \\
\hline 5 & 8.1 & $86 \mathrm{a}$ & $74 \mathrm{a}$ & $62 \mathrm{c}$ \\
\hline 6 & 8.2 & $86 \mathrm{a}$ & $58 \mathrm{~b}$ & $81 \mathrm{a}$ \\
\hline 7 & 8.0 & $96 \mathrm{a}$ & $68 \mathrm{~b}$ & $59 \mathrm{c}$ \\
\hline 8 & 8.4 & $87 \mathrm{a}$ & $52 \mathrm{c}$ & $58 \mathrm{c}$ \\
\hline 9 & 8.2 & $69 \mathrm{~b}$ & $27 \mathrm{~d}$ & $44 \mathrm{~d}$ \\
\hline 10 & 7.8 & $49 \mathrm{c}$ & $38 \mathrm{~d}$ & $44 \mathrm{~d}$ \\
\hline F Test & & $21.31 * *$ & $16.08^{* *}$ & $9.54 * *$ \\
\hline $\mathrm{CV}$ & & $12.79 \%$ & $8.42 \%$ & $13.37 \%$ \\
\hline
\end{tabular}

${ }^{1}$ Means in the same column followed by the same letter are not significantly different according to the Scott-Knott test at $5 \%$ probability. **Significant according to the $\mathrm{F}$ test at $1 \%$ probability. CV: Coefficient of Variation.

Table 2. Initial seed moisture content (SMCi) and moisture content after traditional accelerated ageing (AA) and saturated salt solution accelerated ageing (SSAA) at 41 and $45^{\circ} \mathrm{C}$ and 24,48 , and 72 hours of exposure for ten lots of crambe seeds.

\begin{tabular}{|c|c|c|c|c|c|c|c|c|c|c|c|c|c|}
\hline \multirow{2}{*}{ Lots } & \multirow{2}{*}{ SMCi } & \multicolumn{3}{|c|}{$\mathrm{AA}-41^{\circ} \mathrm{C}$} & \multicolumn{3}{|c|}{$\mathrm{AA}-45^{\circ} \mathrm{C}$} & \multicolumn{3}{|c|}{ SSAA $-41^{\circ} \mathrm{C}$} & \multicolumn{3}{|c|}{ SSAA $-45^{\circ} \mathrm{C}$} \\
\hline & & $24 \mathrm{~h}$ & $48 \mathrm{~h}$ & $72 \mathrm{~h}$ & $24 \mathrm{~h}$ & $48 \mathrm{~h}$ & $72 \mathrm{~h}$ & $24 \mathrm{~h}$ & $48 \mathrm{~h}$ & $72 \mathrm{~h}$ & $24 \mathrm{~h}$ & $48 \mathrm{~h}$ & $72 \mathrm{~h}$ \\
\hline 1 & 8.5 & 25.9 & 31.6 & 34.3 & 27.6 & 33.0 & 33.9 & 9.4 & 9.4 & 9.4 & 9.4 & 10.8 & 9.1 \\
\hline 2 & 8.1 & 27.6 & 31.2 & 35.4 & 26.7 & 32.9 & 34.6 & 10.4 & 9.5 & 9.9 & 9.2 & 10.1 & 9.3 \\
\hline 3 & 8.0 & 27.0 & 33.7 & 34.8 & 27.0 & 32.4 & 36.6 & 10.6 & 9.6 & 9.6 & 8.8 & 9.4 & 9.2 \\
\hline 4 & 8.6 & 25.4 & 32.1 & 36.1 & 28.6 & 31.2 & 34.5 & 10.0 & 11.9 & 10.0 & 9.1 & 10.2 & 9.0 \\
\hline 5 & 8.0 & 24.5 & 30.2 & 33.9 & 28.2 & 31.1 & 33.2 & 10.5 & 9.4 & 9.7 & 9.6 & 10.1 & 8.8 \\
\hline 6 & 8.2 & 27.4 & 29.7 & 34.3 & 28.2 & 32.8 & 34.5 & 9.9 & 9.8 & 9.7 & 9.6 & 10.0 & 9.1 \\
\hline 7 & 8.1 & 25.7 & 33.3 & 36.5 & 27.1 & 31.7 & 32.9 & 10.3 & 9.4 & 9.5 & 9.4 & 10.2 & 9.0 \\
\hline 8 & 8.5 & 26.7 & 34.2 & 37.2 & 27.4 & 32.2 & 33.6 & 10.1 & 9.7 & 9.5 & 9.1 & 10.3 & 9.3 \\
\hline 9 & 8.4 & 28.2 & 32.9 & 36.0 & 30.0 & 33.5 & 35.2 & 10.1 & 10.0 & 9.8 & 10.2 & 11.1 & 9.2 \\
\hline 10 & 7.8 & 27.9 & 33.2 & 35.5 & 28.9 & 35.0 & 36.8 & 10.5 & 9.5 & 10.0 & 9.4 & 9.8 & 9.2 \\
\hline
\end{tabular}

Table 3. Germination of ten lots of crambe seeds after accelerated ageing (AA) at $41{ }^{\circ} \mathrm{C}$ for 24,48 , and 72 hours with results evaluated at 4 and 5 days after seed sowing.

\begin{tabular}{|c|c|c|c|c|c|c|}
\hline \multirow{2}{*}{ Lots } & \multicolumn{3}{|c|}{$\mathrm{AA}-41{ }^{\circ} \mathrm{C}\left(4^{\text {th }}\right.$ day $)$} & \multicolumn{3}{|c|}{$\mathrm{AA}-41^{\circ} \mathrm{C}\left(5^{\text {th }}\right.$ day $)$} \\
\hline & $24 \mathrm{~h}$ & $48 \mathrm{~h}$ & $72 \mathrm{~h}$ & $24 \mathrm{~h}$ & $48 \mathrm{~h}$ & $72 \mathrm{~h}$ \\
\hline & \multicolumn{6}{|c|}{---------------------------------- $\%$-------------------------------- } \\
\hline 1 & $89 a^{1}$ & $86 \mathrm{a}$ & $66 \mathrm{a}$ & 94 a & $89 \mathrm{a}$ & $79 \mathrm{a}$ \\
\hline 2 & $54 \mathrm{c}$ & $47 \mathrm{~d}$ & $27 \mathrm{~d}$ & $73 \mathrm{~b}$ & $71 \mathrm{~b}$ & $43 \mathrm{c}$ \\
\hline 3 & $85 \mathrm{a}$ & $72 \mathrm{~b}$ & $56 \mathrm{~b}$ & $93 \mathrm{a}$ & $91 \mathrm{a}$ & $84 \mathrm{a}$ \\
\hline 4 & $71 \mathrm{~b}$ & $54 \mathrm{c}$ & $42 \mathrm{c}$ & $89 a$ & $81 \mathrm{a}$ & $76 a$ \\
\hline 5 & $81 \mathrm{a}$ & $61 \mathrm{~b}$ & $36 \mathrm{c}$ & $92 \mathrm{a}$ & $87 \mathrm{a}$ & $70 \mathrm{~b}$ \\
\hline 6 & $67 \mathrm{~b}$ & $68 \mathrm{~b}$ & $53 \mathrm{~b}$ & $85 \mathrm{a}$ & $86 a$ & $81 \mathrm{a}$ \\
\hline 7 & $84 a$ & $78 \mathrm{a}$ & $51 \mathrm{~b}$ & $91 \mathrm{a}$ & $84 \mathrm{a}$ & $65 \mathrm{~b}$ \\
\hline 8 & $71 \mathrm{~b}$ & $65 \mathrm{~b}$ & $41 \mathrm{c}$ & $86 a$ & $76 \mathrm{~b}$ & $79 a$ \\
\hline 9 & $61 \mathrm{c}$ & $38 \mathrm{~d}$ & $28 \mathrm{~d}$ & $68 \mathrm{~b}$ & $63 \mathrm{~b}$ & $47 \mathrm{c}$ \\
\hline 10 & $58 \mathrm{c}$ & $45 \mathrm{~d}$ & $33 \mathrm{~d}$ & $69 \mathrm{~b}$ & $69 \mathrm{~b}$ & $50 \mathrm{c}$ \\
\hline F Test & $18.48 * *$ & $26.01 * *$ & $23.96 * *$ & $11.65^{* *}$ & $10.30 * *$ & $16.87 * *$ \\
\hline $\mathrm{CV}$ & $7.95 \%$ & $9.75 \%$ & $12.55 \%$ & $7.04 \%$ & $7.41 \%$ & $11.02 \%$ \\
\hline
\end{tabular}

${ }^{1}$ Means in the same column followed by the same letter are not significantly different according to the Scott-Knott test at $5 \%$ probability. **Significant according to the $\mathrm{F}$ test at $1 \%$ probability. CV: Coefficient of Variation.

Table 4. Germination of ten lots of crambe seeds after accelerated ageing (AA) at $45{ }^{\circ} \mathrm{C}$ for 24,48 , and 72 hours with results evaluated 4 and 5 days after seed sowing.

\begin{tabular}{|c|c|c|c|c|c|c|}
\hline \multirow[b]{2}{*}{ Lots } & \multicolumn{3}{|c|}{$\mathrm{AA}-45^{\circ} \mathrm{C}\left(4^{\text {th }}\right.$ day $)$} & \multicolumn{3}{|c|}{$\mathrm{AA}-45^{\circ} \mathrm{C}\left(5^{\text {th }}\right.$ day $)$} \\
\hline & $24 \mathrm{~h}$ & $48 \mathrm{~h}$ & $72 \mathrm{~h}$ & $24 \mathrm{~h}$ & $48 \mathrm{~h}$ & $72 \mathrm{~h}$ \\
\hline & & $2---$ & & & ---- & \\
\hline 1 & $81 \mathrm{a}^{1}$ & $49 \mathrm{a}$ & $44 \mathrm{a}$ & $85 \mathrm{a}$ & $77 \mathrm{a}$ & $61 \mathrm{a}$ \\
\hline 2 & $52 \mathrm{c}$ & $55 \mathrm{a}$ & $44 \mathrm{a}$ & $60 \mathrm{~b}$ & $67 \mathrm{~b}$ & $60 \mathrm{a}$ \\
\hline 3 & $81 \mathrm{a}$ & $51 \mathrm{a}$ & $29 \mathrm{~b}$ & $87 \mathrm{a}$ & $83 \mathrm{a}$ & $48 \mathrm{~b}$ \\
\hline 4 & $66 \mathrm{~b}$ & $52 \mathrm{a}$ & $28 \mathrm{~b}$ & $73 \mathrm{a}$ & $70 \mathrm{~b}$ & $52 \mathrm{a}$ \\
\hline 5 & $66 \mathrm{~b}$ & $35 \mathrm{~b}$ & $15 \mathrm{c}$ & $77 \mathrm{a}$ & $61 \mathrm{~b}$ & $36 \mathrm{~b}$ \\
\hline 6 & $62 \mathrm{~b}$ & $57 \mathrm{a}$ & $27 \mathrm{~b}$ & $73 \mathrm{a}$ & $75 \mathrm{a}$ & $49 \mathrm{~b}$ \\
\hline 7 & $69 \mathrm{~b}$ & $32 \mathrm{~b}$ & $4 \mathrm{~d}$ & $81 \mathrm{a}$ & $48 \mathrm{c}$ & $16 \mathrm{c}$ \\
\hline 8 & $65 \mathrm{~b}$ & $26 \mathrm{~b}$ & $15 \mathrm{c}$ & $81 \mathrm{a}$ & $67 \mathrm{~b}$ & $24 \mathrm{c}$ \\
\hline 9 & $44 \mathrm{c}$ & $17 \mathrm{c}$ & $0 \mathrm{~d}$ & $54 \mathrm{~b}$ & $28 \mathrm{~d}$ & $4 \mathrm{~d}$ \\
\hline 10 & $37 \mathrm{c}$ & $13 \mathrm{c}$ & $0 \mathrm{~d}$ & $46 \mathrm{~b}$ & $28 \mathrm{~d}$ & $3 \mathrm{~d}$ \\
\hline F Test & $10.53 * *$ & $13.95 * *$ & $24.07 * *$ & $9.57 * *$ & $10.01 * *$ & $30.34 * *$ \\
\hline $\mathrm{CV}$ & $14.24 \%$ & $22.38 \%$ & $28.78 \%$ & $12.46 \%$ & $14.85 \%$ & $26.37 \%$ \\
\hline
\end{tabular}

${ }^{1}$ Means in the same column followed by the same letter are not significantly different according to the Scott-Knott test at $5 \%$ probability. $* *$ Significant according to the $\mathrm{F}$ test at $1 \%$ probability. CV: Coefficient of Variation. 
Table 5. Germination of ten lots of crambe seeds submitted to accelerated ageing via the saturated salt solution method (SSAA) at 41 and $45^{\circ} \mathrm{C}$ and for 24,48 , and 72 hours.

\begin{tabular}{lcccccc}
\hline \multirow{2}{*}{ Lots } & \multicolumn{3}{c}{ SSAA - $41{ }^{\circ} \mathrm{C}$} & \multicolumn{3}{c}{ SSAA - $45{ }^{\circ} \mathrm{C}$} \\
\cline { 2 - 6 } 1 & $24 \mathrm{~h}$ & $48 \mathrm{~h}$ & $72 \mathrm{~h}$ & $24 \mathrm{~h}$ & $48 \mathrm{~h}$ & $72 \mathrm{~h}$ \\
\hline & $93 \mathrm{a}^{1}$ & $81 \mathrm{a}$ & $68 \mathrm{a}$ & $90 \mathrm{a}$ & $76 \mathrm{a}$ & $58 \mathrm{a}$ \\
3 & $78 \mathrm{c}$ & $70 \mathrm{a}$ & $57 \mathrm{~b}$ & $79 \mathrm{~b}$ & $26 \mathrm{~d}$ & $37 \mathrm{~b}$ \\
4 & $86 \mathrm{~b}$ & $78 \mathrm{a}$ & $51 \mathrm{~b}$ & $83 \mathrm{a}$ & $56 \mathrm{~b}$ & $55 \mathrm{a}$ \\
5 & $78 \mathrm{c}$ & $72 \mathrm{a}$ & $43 \mathrm{c}$ & $67 \mathrm{c}$ & $50 \mathrm{~b}$ & $33 \mathrm{~b}$ \\
6 & $73 \mathrm{c}$ & $75 \mathrm{a}$ & $44 \mathrm{c}$ & $68 \mathrm{c}$ & $41 \mathrm{c}$ & $28 \mathrm{c}$ \\
7 & $74 \mathrm{c}$ & $76 \mathrm{a}$ & $38 \mathrm{c}$ & $67 \mathrm{c}$ & $52 \mathrm{~b}$ & $37 \mathrm{~b}$ \\
8 & $85 \mathrm{~b}$ & $73 \mathrm{a}$ & $53 \mathrm{~b}$ & $73 \mathrm{~b}$ & $73 \mathrm{a}$ & $49 \mathrm{a}$ \\
9 & $72 \mathrm{c}$ & $64 \mathrm{a}$ & $47 \mathrm{~b}$ & $66 \mathrm{c}$ & $56 \mathrm{~b}$ & $26 \mathrm{c}$ \\
10 & $62 \mathrm{~d}$ & $41 \mathrm{~b}$ & $28 \mathrm{~d}$ & $56 \mathrm{~d}$ & $40 \mathrm{c}$ & $21 \mathrm{~d}$ \\
\hline F Test & $50 \mathrm{e}$ & $33 \mathrm{~b}$ & $34 \mathrm{~d}$ & $45 \mathrm{e}$ & $27 \mathrm{~d}$ & $18 \mathrm{~d}$ \\
CV & $29.42 * *$ & $21.59 * *$ & $15.23 * *$ & $14.12 * *$ & $20.75 * *$ & $33.38^{* *}$ \\
\hline
\end{tabular}

${ }^{1}$ Means in the same column followed by the same letter are not significantly different according to the Scott-Knott test at $5 \%$ probability. **Significant according to the $\mathrm{F}$ test at $1 \%$ probability. CV: Coefficient of Variation.

this test include rapidity, ease of execution, and that it can be conducted simultaneously with the germination test (Nakagawa, 1999; Barros et al., 2002; Marcos-Filho, 2005; Matthews et al., 2011). Bhéring et al. (2000) studied cucumber seeds and also found that the initial germination count could be consistently used to provide preliminary information on seed lot vigour. Matthews et al. (2011) also reported that the first germination count could be used to efficiently classify corn seed lots. The efficacy of the seedling emergence test (Table 1) is due to conditions such as temperature, moisture, and physicochemical characteristics of the substrate that could be controlled and standardized, such that, if differences were found, they could be more creditably ascribed to differences between the physiological potential of seed lots. The rapid increase in seed moisture content observed during the first ageing period (Table 2) is explained by the low matrix potential of the seeds - the dryer the seeds, the faster they absorb water (Bewley and Black, 1994). After the traditional accelerated ageing test, variations in seed moisture content between lots, given the different combinations of temperature and exposure periods, were above the acceptable limit of two percentage points (MarcosFilho, 1999a) (Table 2). This level of variation could compromise test reliability since moistened seeds are more conducive to test conditions and subsequent deterioration. Nevertheless, this was not observed in the present study (Tables 3 and 4). Unlike the traditional test, SSAA maintained seed moisture variation between lots within the limits proposed by Marcos-Filho, (1999a). The traditional accelerated ageing test at $41{ }^{\circ} \mathrm{C}$ for 48 hours was shown to be promising for the evaluation of crambe seed lots (Table 3 ). Several studies have reported satisfactory results using the accelerated ageing at $42{ }^{\circ} \mathrm{C}$ and 48 hours for brassica seeds such as broccoli (Mello et al., 1999), kale and cabbage (Costa et al., 2008). However, Barros et al. (2002) worked with tomato seeds and observed that ageing at $41{ }^{\circ} \mathrm{C}$ for 48 hours could not be used to detect vigour differences between seed lots. A study on crambe seeds suggested that temperatures of 41 or $43{ }^{\circ} \mathrm{C}$ led to greater sensitivity when ageing seeds for 72 hours (Werner et al., 2013). This result contradicts the findings of the present study, which showed that deterioration is mainly caused by long exposure $(72 \mathrm{~h})$ and that shorter accelerated ageing periods should be used in the traditional method (Table 3). Evaluation on the $5^{\text {th }}$ day after sowing was not effective for separating seed lots (Table 3). Therefore, as recommended by Marcos-Filho (1999a), the ageing test evaluations could be carried out on the date of the first germination count. The severe seed damage caused by ageing at $45{ }^{\circ} \mathrm{C}$ (Table 4) was also reported for common beans
(Bertolin, 2011), and cauliflower seeds (Kikuti and MarcosFilho, 2008) where germination was greatly reduced after the 48 hour period and no germination was observed after the 72 hour period. The high germination rates observed under SSAA (Table 5) may result from the salt $(\mathrm{NaCl})$ used in this method that reduces relative air humidity inside the plastic germination box to approximately $76 \%$. Lower humidity in turn causes slower water absorption (Jianhua and McDonald, 1997), which is reflected in seed moisture content (Table 2). Reduced water absorption and less intense deterioration lead to less severe and more consistent impacts on seeds (Panobianco and Marcos-Filho, 2001).

Therefore, SSAA is a useful alternative for evaluating crambe seed lots given that crambe seeds are small and typically more sensitive to high temperatures and humidity. In addition, according to Marcos-Filho (2005), SSAA suppresses microorganism development due to lower seed moisture levels. Exposing the seeds for 24 hours at 41 and 45 ${ }^{\circ} \mathrm{C}$ allowed successful discrimination of seed lot vigour. Similar to the results of a study on carrot seeds (Rodo et al., 2000), the saturated salt solution ageing method led to lower and more uniform moisture content in crambe seeds (Table 2). These results show the advantages - reduced deterioration, less drastic and more uniform results - of using the SSAA method for small seeds instead of the traditional method.

The saturated salt solution procedure was found to be efficient for several small seeded species such as green pepper (Panobianco and Marcos-Filho, 1998), carrot (Rodo et al., 2000), melon (Torres and Marcos-Filho, 2003), lentil (Freitas and Nascimento, 2006), radish (Avila et al., 2006), and wild radish (Nery et al., 2009).

\section{Materials and Methods}

\section{Seeds}

Ten seed lots of crambe cv. FMS Brilhante were used with an initial seed moisture content varying between 7.8 and $8.6 \%$ (fresh weight basis). The seed lots were kept in impermeable packages during the experiment period and stored in a cold room at $10{ }^{\circ} \mathrm{C}$ and $60 \%$ relative humidity $(\mathrm{RH})$.

\section{Determining seed moisture}

Seed moisture was determined by the oven method in which $2 \mathrm{~g}$ of seed subsamples were maintained at $105 \pm 3{ }^{\circ} \mathrm{C}$ for 24 hours (Brasil, 2009). These measurements were carried out before and after seed ageing and expressed as percentages (wet basis). 


\section{Germination test}

Four replications of 50 seeds for each lot were placed inside $11 \times 11 \times 3.5 \mathrm{~cm}$ plastic germination boxes with approximately $300 \mathrm{~g}$ of a sieved and sterilized sand substrate. Fifty seeds were then distributed over the sand surface and covered with a sand layer approximately $0.5 \mathrm{~cm}$ thick. The substrate had been previously wetted with enough $0.2 \%$ $\mathrm{KNO}_{3}$ to raise the sand moisture level to $70 \%$ of its water holding capacity. The germination test was carried under alternating temperatures of 20 and $30{ }^{\circ} \mathrm{C}$ and a photoperiod of 12 hours. Evaluation took place four and seven days after the beginning of the test. The results were expressed as percentages of normal seedlings (Brasil, 2009).

The first germination count was conducted simultaneously with the germination test. The percentage of normal seedlings found on the fourth day after germination was considered as the result of this test (Nakagawa, 1999).

\section{Accelerated ageing test - traditional method}

Five grams of seed from each lot were spread in a single layer over a stainless steel screen inside plastic germination boxes $(11 \times 11 \times 3.5 \mathrm{~cm})$. Water jacket ageing chambers with $40 \mathrm{~mL}$ of deionized water were also placed within the boxes. These boxes were then maintained at 41 and $45^{\circ} \mathrm{C}$ for 24,48 , and 72 hours. Afterwards, a germination test was performed as previously described. Evaluations were made at four and five days after seed sowing and the results were expressed as a percentage of normal seedlings.

\section{Accelerated ageing test with saturated salt solution}

The procedures in the SSAA test were the same as those in the traditional method except that the $40 \mathrm{~mL}$ of deionized water was replaced with the same volume of a saturated salt solution (40 g of $\mathrm{NaCl}$ in $100 \mathrm{~mL}$ of water) (Jianhua and McDonald, 1997). This solution produced a relative humidity of approximately $76 \%$ within the germination boxes. The results were expressed as a percentage of normal seedlings.

\section{Seedling emergence in laboratory test}

The test was conducted in $16 \times 27 \times 9.0 \mathrm{~cm}$ germination boxes containing $1,000 \mathrm{~g}$ of sieved soil that had been previously moistened to $70 \%$ of water holding capacity. Four replications of 50 seeds each were sown at a depth of $2 \mathrm{~cm}$. Water was added to the boxes every day. The boxes remained inside the laboratory without temperature or humidity controls. During the test, the mean temperature of the seed laboratory was of $23{ }^{\circ} \mathrm{C}$ with a minimum of $15^{\circ} \mathrm{C}$ and a maximum of $32{ }^{\circ} \mathrm{C}$. Fourteen days after sowing, emerged seedlings with hypocotyls $1 \mathrm{~cm}$ above the substrate were counted. The results were expressed as a percentage of emerged seedlings (Nakagawa, 1999).

\section{Statistical procedure}

Statistical analysis was performed separately for each test and each variable of the ageing test and was completely randomized with four repetitions. Data were submitted to analysis of variance via the $\mathrm{F}$ test. Means were compared by the Scott-Knott test at the 5\% level of probability (Banzatto and Kronka, 2006).

\section{Conclusion}

Our results showed that the traditional method for accelerated ageing of crambe seeds should be executed for 48 hours and at $41{ }^{\circ} \mathrm{C}$, whereas the saturated salt solution method should be performed for 24 hours at either 41 or $45{ }^{\circ} \mathrm{C}$. Seedling assessment should occur on the fourth day regardless of methodology.

\section{Acknowledgments}

This study received financial support from the following Brazilian research organisations: CNPq - Conselho Nacional de Desenvolvimento Científico e Tecnológico (Process 303321/2009-1), (National Council for Scientific and Technological Development) and Fapesp - Fundação de Amparo à Pesquisa do Estado de São Paulo (Process 2006/57900-0), (Research Support Foundation of the State of Sao Paulo).

\section{References}

Ávila PFV, Villela FA, Ávila MSV (2006) Teste de envelhecimento acelerado para avaliação do potencial fisiológico de sementes de rabanete. Rev Bras Sementes. 28:52-58.

Banzatto DA, Kronka SN (2006) Experimentação agrícola, 4th edn. Funep, Jaboticabal.

Barros DI, Nunes HV, Dias DCFS, Bhéring MC (2002) Comparação entre testes de vigor para avaliação da qualidade fisiológica de sementes de tomate. Rev Bras Sementes. 24:12-16.

Bertolin DC, Sá ME, Moreira ER (2011) Parâmetros do teste de envelhecimento acelerado para determinação do vigor de sementes de feijão. Rev Bras Sementes. 33:104-112.

Bewley JD, Black M (1994) Seeds: physiology of development and germination. 1st edn. Plenum Press, New York.

Bhéring MC, Dias DCFS, Gomes JM, Barros DI (2000) Métodos para avaliação do vigor de sementes de pepino. Rev Bras Sementes. 22:171-175.

Brasil (2009) Ministério da Agricultura, Pecuária e Abastecimento - Secretaria de Defesa Agropecuária. Regras para análise de sementes. Mapa/ACS, Brasília, p 344.

Costa CJ, Trzeciak MB, Villela FA (2008) Potencial fisiológico de sementes de brássicas com ênfase no teste de envelhecimento acelerado. Hortc Bras. 26:144-148.

Desai BB (2004) Seeds handbook: biology, production processing and storage. 2nd edn. Marcel Dekker, New York, p 787.

Dutra AS, Vieira RD (2006) Accelerated ageing test to evaluate seed vigor in pumpkin and zucchini seeds. Seed Sci Technol. 34:209-214.

Freitas RA, Nascimento WM (2006) Teste de envelhecimento acelerado em sementes de lentilha. Rev Bras Sementes. 28:59-63.

Ista (2000) International Seed Testing Association. What is seed vigour? ISTA News Bulletin. 121:12-13.

Jianhua Z, McDonald MB (1997) The saturated salt accelerated aging test for small seeded crops. Seed Sci Technol. 25:123-131.

Kikuti ALP, Marcos-Filho J (2008) Physiological potential of cauliflower seeds. Sci Agric, 65:372-380.

Marcos-Filho J (1999a) Teste de envelhecimento acelerado. In: Krzyzanowski FC, Vieira RD, França-Neto JB (eds) Vigor de sementes: conceitos e testes. Abrates, Londrina. 
Marcos-Filho J (1999b) Testes de vigor: importância e utilização. In: Krzyzanowski FC, Vieira RD, França-Neto JB (eds) Vigor de sementes: conceitos e testes. Abrates, Londrina.

Marcos-Filho J (2005) Fisiologia de sementes de plantas cultivadas, 1 st edn. Fealq, Piracicaba.

Masetto TE, Quadros JB, Moreira FH, Ribeiro DM, Benites Junior T, Rezende RKS (2009) Qualidade fisiológica e sanitária de sementes de crambe produzidas no Estado de Mato Grosso do Sul. Revista Brasileira de Oleaginosas e Fibrosas. 13:107-113.

Matthews S, Wagner MH, Ratzenboeck A, Khajeh Hosseini M, Casarini E, El Khadem R, El Yakhlifi M, Powell AA (2011) Evaluation of early counts of radicle emergence during germination as a repeatable and reproducible vigour test for maize. Seed Testing International.141:39-45.

Mello SC, Spinola MCM, Minami K (1999) Métodos de avaliação da qualidade fisiológica de sementes de brócolos. Sci Agric. 56:1151-1155.

Nakagawa J (1999) Testes de vigor baseados na avaliação das plântulas. In: Krzyzanowski FC, Vieira RD, FrançaNeto JB (eds) Vigor de sementes: conceitos e testes. Abrates, Londrina.

Nery MC, Carvalho MLM, Guimarães RM (2009) Testes de vigor para avaliação da qualidade de sementes de nabo forrageiro. Informativo Abrates. 19:9-20.

Panobianco M, Marcos-Filho J (1998) Comparação entre métodos para avaliação da potencial fisiológico de sementes de pimentão. Rev Bras Sementes. 20:306-310.

Panobianco M, Marcos-Filho J (2001) Envelhecimento acelerado e deterioração controlada em sementes de tomate. Sci Agric. 58:525-531.

Paulose B, Kandasamy S, Dhankher OP (2010) Expression profiling of Crambe abyssinica under arsenate stress identifies genes and gene networks involved in arsenic metabolism and detoxification. BMC Plant Biol. 10:1-12.
Powell AA (1995) The controlled deterioration test. In: Venter HA (ed) Seed Vigour Testing Seminar, 1st edn. The International Seed Testing Association, Copenhagen.

Ramos NP, Flor EPO, Mendonça EAF, Minami K (2004) Envelhecimento acelerado em sementes de rúcula (Eruca sativa L.). Rev Bras Sementes. 26:98-103.

Rodo AB, Panobianco M, Marcos-Filho J (2000) Metodologia alternativa do teste de envelhecimento acelerado para sementes de cenoura. Sci Agric. 57:289292.

Silva JB, Vieira RD, Panobianco M (2006) Accelerated ageing and controlled deterioration in beetroot seeds. Seed Sci Technol. 34:265-271.

TeKrony DM (1995) Accelerated aging. In: Venter HA (ed.) Seed vigour testing seminar, 1st edn. International Seed Testing Association, Copenhagen.

TeKrony DM (2003) Precision is an essential component in seed vigour testing. Seed Sci Technol. 31:435-447.

TeKrony DM, Egli DB (1991) Relationship of seed vigor to crop yield: a review. Crop Sci. 31:816-822.

Torres SB, Marcos-Filho J (2003) Accelerated aging of melon seeds. Sci Agric. 60:77-82.

Vieira RD, Bittencourt SRM, Panobianco M (2003) Seed vigor: an important component of seed quality in Brasil. Ista News Bulletin. 126:21-22.

Werner ET, Lopes JC, Gomes Junior D, Luber J, Amaral JAT (2013) Accelerated aging test to evaluate the quality of crambe (Crambe abyssinica Hochst - Brassicaceae) seed physiology. Idesia. 31:35-43. 